Article

\title{
Generation X School Leaders as Agents of Care: Leader and Teacher Perspectives from Toronto, New York City and London
}

\author{
Karen Edge *, Katherine Descours and Keren Frayman \\ UCL Institute of Education, 20 Bedford Way, London WC1H 0AL, UK; kdescours@gmail.com (K.D.); \\ keren.frayman@gmail.com (K.F.) \\ * Correspondence: k.edge@ucl.ac.uk; Tel.: +44-207-612-6443 \\ Academic Editor: Gregor Wolbring \\ Received: 3 March 2016; Accepted: 28 March 2016; Published: 31 March 2016
}

\begin{abstract}
This paper draws on evidence from our three-year Economic and Social Research Council (ESRC)-funded research study of the lives, careers, experiences and aspirations of Generation $X$ (under 40 years of age) principals and vice-principals in London, New York City, and Toronto. More specifically, the paper examines interview evidence from nine school-based studies in which nine leaders and 54 teachers discuss their perspectives on leaders' care of their staff members. The evidence demonstrates that leaders and teachers both place a high level of importance on leaders' ability and willingness to be supportive, understanding, and approachable. Teachers also expect leaders to serve as advocates for and role models of good work/life balance. While the school-level studies take place in radically different city-based contexts, the expectation of leaders' care for teachers transcends different accountability and policy structures. Both groups focus their discussion on work/life balance and, more specifically, the need for leaders to understand that teachers are people with lives beyond school. The paper highlights implications for policy, practice, and future research.
\end{abstract}

Keywords: leadership; Generation X; global cities; care; collective efficacy; work/life balance

\section{Introduction}

Care emerged as a topic of interest within school and educational leadership research in the early 1980s. During this period, empirical and theoretical discussions often aligned to moral dimensions of leadership and the centrality of values within discussions of educational administration [1] and schools [2,3]. Schools were called upon to develop comprehensive focus on creating environments supporting health and happiness [2] and promoting their own personal growth and health [4]. Collectively, these scholars often coupled schools and notions of care with a focus on the role of leaders. However, from the early 2000s, research interest in care slowed and remained empirically frail. As a result, school-level and leadership-related care as research subjects persist in their infancy and without much empirical rigor.

In the last several years, a renewed interest in leadership and care materialized within educational leadership [5] and beyond [6]. This paper dovetails with this re-emerging focus and examines leadership and care within schools led by Generation X (under-40-year-old) leaders in three large global cities. As such, the paper not only contributes to discussions of leader-teacher relationships but also marks the understanding of a new generation of leaders entering the school system in the most senior roles.

Our interest in Generation X (GenX) leaders emerged in 2008, when our London-based research team observed a new, younger generation of professionals entering senior school leadership posts in several urban centers. We believe that their entry marks an important transition for education 
systems. First, these leaders are from Generation X, born between 1966 and 1980. GenXers bring a new set of generational propositions, expectations, and aspirations to their school leadership posts. They are widely viewed as independent and self-sufficient [7] and heavily committed to personal and work-based friendships and social/peer networks [8]. These oft-shared traits shape GenXers' identified desire for collaboration [9], mobility [10], diversity, and more experimental structures in organizations [11] and work/life balance [8]. Many of these characteristics are markedly different from those of their predecessors-baby boomers. Second, while there has yet to be a definitive analysis of the age of leaders participating in seminal educational leadership research studies, it has always been our assumption that, barring the current emerging evidence base on novice leaders, much of what is known about leadership practices has been generated by and for the now retiring generation of scholars and school leaders.

GenXers appear to be markedly different from their baby-boomer predecessors in their approach to work, careers, collaboration, and work/life priorities [12]. As a result, GenX school leaders may also bring a new set of expectations, experience, and aspirations to school leadership careers. We also wonder if, and how, these identified generational patterns influence the way in which GenX school leaders approach their work and lives. If generational assumptions hold true, then the rise in the number of GenX school leaders may have important implications for leadership recruitment, development, and retention.

While we acknowledge the growing body of recent literature on novice leaders [13], educational leadership research has rarely been stratified to examine the possible generational influences on leadership experience and practice. As a result, there remains little research exploring the experience and aspirations of the emerging population of GenX school leaders [14] within and beyond education. As this new generation of leaders should have at least 25 years remaining in their careers, understanding more about their motivations and aspirations is important for policymakers, researchers, and leaders.

To address this knowledge gap, our three-year research study engages cohorts of 20-25 GenX school leaders in each of three global cities [15]—London, New York City and Toronto [16]. The Global City Leaders (GCL) research project, funded by the Economic and Social Research Council (ESRC-UK), examines the careers, lives, leadership, and future aspirations of GenX principals and vice-principals. In 2011, we launched the study by establishing city-based advisory groups comprised of 49 academic, policy, and practice leaders. School leaders were recruited to participate in two annual interviews and optional GCL networking events. We also conducted nine school-level studies as examples of GenX leadership in practice.

Global City Leaders: Expressions and Expectations of Care

Our original interview and school-level analyses $[17,18]$ uncovered several emerging patterns within and across cities. Leaders consistently reported struggling to achieve personal work/life balance, striving to support teachers' work/life balance, and outright commitment to collaboratively leading their schools. The majority of our GenX leaders discussed their school-based work with what we have come to define as an "ethic of care" for the adults in their school buildings. We were surprised at the unilateral emphasis leaders placed on caring for teachers. While we did not specifically ask if, or how, leaders care for their staff, almost all said they wanted to encourage teachers' work/life balance and sense of being supported. Often, leaders linked their motivation for caring for teachers as strategies to enhance teachers' happiness and confidence within and beyond the school. Leaders report also wanting to improve teacher performance in the classroom and decisions to remain in the profession.

Throughout our study, leaders consistently discuss the value they place on nurturing teachers, capacity-building, and talent-spotting [17]. Leaders also explain their aspirations for work/life balance, their awareness of teachers' need for the same, and their belief that leaders need to care for their colleagues professionally and personally [19]. However, at the same time, many GenX leaders across 
the three cities shared how they had not, and still do not, have good role models for their own work/life balance. While they were caring for others, they were not caring for themselves [12].

This paper explores how nine leaders and 54 teachers across nine school-level studies respond, formally and informally, to the question: Is it the leader's role to care for his or her staff? Our analysis dovetails with the emerging and expanding interest in teacher [20-22] and leader wellbeing and work/life balance [23-25] and leader care in schools [5] and beyond [6]. More specifically, while the school-based studies did not link leader actions to measures of teacher and student attainment and learning, we intend to explore how leaders believe they express care and how teachers have come to expect and anticipate care from their leaders and its influence. Leaders' acts of caring for the emotional lives of teachers can influence school culture, teacher commitment, teacher collective efficacy and commitment which, in turn, influences improved student learning [26,27]. The paper encapsulates our initial contribution to the growing discussion of how leaders influence teachers.

The paper begins with an introduction to the GCL study and a light-touch review of the research literature informing the overall study design and conceptualization including global cities, generations, "generations at work" and GenX. To situate our discussion of leadership and care, we provide a brief summary of research linked to the leaders' influence on teachers and students. More specifically, we highlight evidence on the influence and importance of leader care for employees. Next, we describe our overall GCL research program, focusing on the strategies employed to gather and analyze the nine school-based studies. We detail our grounded theory approach [28] applied to the analysis of leader and teacher transcripts and present the five dominant categories of leader care-focused actions and priorities: (1) support and understanding; (2) approachability; (3) knowledge of teachers' personal lives; (4) modeling balance between work and life; and (5) caring for teachers' personal wellbeing. The findings and discussion suggest that while all leaders discuss prioritizing their care of teachers, most enact care as a means of supporting and retaining staff and increasing work/life balance and workplace satisfaction. Similarly, teachers consistently emphasize the positive influence of leaders' understanding, approachability, and recognition of the importance of their lives beyond school. Teachers and leaders also discuss the influence of personal relationships and care on their own classroom practice and student achievement.

This paper makes three unique contributions. First, our evidence is gathered from a new generation of leaders who are recognized [12] to be more collaborative and work/life-balance-minded. However, we are aware that their views on nurturing teachers may simply be informed by current thinking about leadership practice as well as the influence of their generational tendencies. Second, our evidence looks exclusively at leaders in urban contexts across three very different education systems. Third, while our policy/practice studies [29-32] note significant differences in the role of leaders and the structures, supports, and levels of accountability in each system, leaders' and teachers' views remain surprisingly consistent. The generational and international comparative elements of the study create a departure point for considering how leaders are approaching their roles, the expectations their teachers hold of them, and the potential implications for education systems in the future.

In this paper, we do not disaggregate the findings by the different sites of our research or by demographic attributes of the participating principals. This is because our initial cross-city analysis did not highlight any specific differences between the cities in how leaders discuss and/or are expected to approach their role in caring for teachers. Similarly, we also do not stratify our analysis by leaders' gender, background, and years of experience.

\section{Literature Review}

We begin with a brief summary of research related to leadership and the enactment of care followed by an examination of the relationship between leadership, employee experience, wellbeing and satisfaction. We conclude with an overview of the evidence influencing the overall design and conceptualization of our work drawing from sociology, psychology, and business including: generational theory; generational differences by cohort; and, global cities. 
Leadership and the enactment of care. Gilligan [33] and Noddings [34] have anchored much of the educational discussion of caring. Subsequently, studies within and beyond education have examined relationships between leaders' roles in providing support and care for their staff [18,35-37] and associated positive influences on employees' and teachers' experience of and commitment to work. For example, Hargreaves [36] prioritizes the emotions of teaching and teacher development for school leaders and highlights the centrality of teacher emotions to educational improvement and outcomes.

Emerging from an interest in commitment to caring as a means of personal growth, a group of scholars argue for the building of caring schools and communities [3]. This work, linked directly to leadership practice, is also closely related to a body of work that emphasizes using values or moral reasoning to inform ethical response to problematic situations involving ethical dilemmas [38,39].

More recently, several new contributions to and conceptualizations of leader care have emerged in corporate [6,40,41] and educational leadership [5] to address what has been a limited scholarly consideration at best [6]. Discussions posit that leaders "will always be judged by their followers against their ability to demonstrate that they care" ([6], p. 317). Within education, researchers have very recently proposed and tested a robust preliminary model of caring leadership [5] that includes attentiveness, motivational displacement, situationality, mutuality, and authenticity. All of these developments further point to the need to develop a deeper conceptual and empirical understanding of leader enactment of care and the potential influence on teachers.

In this light, studies have also linked the importance of leader-teacher relationships to teacher retention alongside work conditions and school-level policies [42]. We believe there is a nexus of the arrival of a newer generation of leaders who self-identify as being highly collaborative and relationally driven, with the increasing pressure on many schools and school systems to retain teachers in their roles. This creates a unique point in time where leaders' demonstrations of care may be an important factor in teachers' intention to remain in the profession. Evidence from our preliminary and very small-scale study will examine how GenX leaders and their teachers consider the role of leaders in caring for staff.

Leadership and employee experience, wellbeing, and satisfaction. A growing body of corporate research explores relationships between leader behavior and priorities and employee wellbeing, "work/life benefits" [43], or work/life support [44,45]. However, the same studies also report that the links between work/life balance and work performance remain contested. Work-related stress has also been mitigated by strategies to promote wellbeing at work [45-47] and leaders' demonstrations of consideration and support [46]. The evidence suggests that leaders' own personal prioritization of work/life balance has been found to positively influence employees' feelings of being supported [43-45], job satisfaction [44,45], and organizational loyalty [44,45]. Similarly, leader stress and poor wellbeing habits have been linked to issues with follower stress and wellbeing [46]. Much of the business research related to leadership and work conditions is tied, to some degree, to conceptions of transformational leadership, with transformational leaders described as:

the leader moving the follower beyond immediate self-interests through idealized influence (charisma), inspiration, intellectual stimulation, or individualized consideration. It elevates the follower's level of maturity and ideals as well as concerns for achievement, self actualization, and the well-being of others, the organization, and society ([48], p. 11).

Transformational leadership has been evidenced to influence employee job satisfaction [46], reduce employee stress levels, and increase reported levels of wellbeing [46]. Transformational leadership influences wellbeing and self-efficacy [47] through perception of work characteristics and creating and supporting meaningful work [49]. Similarly, transformational leadership has been directly associated with leaders' demonstration of attention to followers' needs and an ethic of care for employees [41]. While the evidence remains inconclusive on many of the direct relational links between leader enactment of care related to work/life balance and support, transformational leadership provides the groundwork for a discussion of how the prioritization of employee wellbeing may be identified and interpreted in schools. 
Educationally focused transformational leadership studies evidence the importance of school-level relationships and leaders' ability to meet individuals' emotional needs and thus increase employee satisfaction [50-52]. Additional evidence linking teacher job satisfaction to school and student performance $[36,53]$ often focuses on principal behaviors including listening, praising, supporting, and committing to care for the needs of teachers [53-55]. While these studies emphasize the role of leaders' tending to teachers' needs, they focus most exclusively on job-related care. In the context of our school-based analysis, we interpret care, as defined through these models, to include supporting the overall wellbeing, satisfaction, and growth of teachers.

Importantly, a more nuanced understanding of how leaders influence teachers has emerged organized along four pathways of influence: Emotions Path, Rational Path, Organizational Path, and Family Path [27]. The emotional pathway, which includes "the feelings, dispositions, or affective states of staff members, both individually and collectively" ([27], p. 675) provides an interesting and important backdrop for our analysis of GenX leaders and their care for teachers. More recently ([26], p. 570), Collective Teacher Efficacy (CTE) has been described as the "level of confidence a group exudes in its capacity to organize and execute the tasks required to reach desired goals" and outline four transformational leadership practices that influence CTE: inspiring group purpose, providing individualized support, modeling, and holding high performance expectations [26]. Based on our analysis of the school-based studies, leader and teacher discussions of leader care directly relate to the emotional path and most specifically to CTE. As such, in the findings section, we center our discussion of leader actions to support teachers within this model and examine leader and teacher perceptions of leaders' actions that influence their own personal and professional work. When first reviewing our school-based leader and teacher GCL evidence, all leaders' and most teachers' comments about leader care for teachers aligned very closely with those actions linked to transformational leadership practices.

Generations. Generations [56] are often described in one of three ways: chronological—bounded by age [57,58]; social—bounded by shared social experiences [58]; or political—bounded by shared historical experience [57]. Life-course perspectives may also account for the evolution of generational attitudes over time as a result of life circumstances [59]. Similarly, the notion of active and passive generations [59] suggests that successive generations are often passive recipients of the actions and structures of active ones. A key motivation for examining GenX leaders is the potential that as the passive generation, they may feel they are passive recipients, and perhaps inheritors, of the policy contexts and school structures informed by the active generation, baby boomers. While there are variations in all patterns between and within generations, they represent a helpful boundary for research and policy consideration.

In most cities, the current school-level workforce is comprised of three main generations. The most senior generation, baby boomers, were named after the accelerated birth-rate "boom" following the Second World War. Boomers have been described as workaholic, quality-minded, and team-players interested in title-based recognition [8]. Boomers also prioritize work and self-fulfillment, at times above family [60]. At the other end of the age spectrum are GenerationY (GenYs) or millennials (born between 1978 and 1990). GenYs are highly techno-literate as a result of the evolution of personal computers, the internet, and social networking [61]. They often prioritize digital working and crave opportunities for learning, teamwork, and real-time constant technology-facilitated connections with peers and social network-based contacts [61]. Growing up in more diverse and tolerant societies, GenYs are well-versed in and committed to equality. They also strive to be heard and are comfortable challenging authority [7].

Growing up in the 1970s and 1980s, GenXers are often named "latchkey kids" to reflect their status as the first independent generation, resulting from the en masse entering of women into the workforce. They grew up in the most rapidly evolving technological era and tend to be globally minded, techno-savvy, informal [8], and collaborative [9]. GenXers are less patient with their careers and less willing to wait for promotion than boomers $[9,62,63]$ GenXers are also often more dissatisfied 
with their careers than other generations [64] and often expect immediate recognition through praise, promotion, and increase in salary [65].

As three generations are actively engaging in teaching and leading in most schools, the imperative for understanding the potential generational implications of the current educational workforce is mounting. There remains a rather limited body of evidence on generations at work in schools. Currently, strands of education-focused generational research relate to GenY teachers [66-69], teacher generational mix [70-72], intergenerational communication [73,74], generational career patterns [75], generational leadership perspectives [76], and technology use [77,78].

While there is an established and accepted research base confirming leaders' influence on schooland teacher-level actions and beliefs and, in turn, leaders' influence on student achievement [26,79-81], there remains little acknowledgement of the pending demographic shift in educational leaders worldwide and the potential influence this may have on leadership styles, skills, and priorities. Even with the emerging focus on generational patterns in schools, there is little research exploring the work and lives of GenX leaders, who are quickly entering or currently holding school-level leadership positions. More specifically, as a new generation of leaders enters the top roles in schools, there is the possibility of a shift in priorities, style, and approach to both leading schools and their careers. Our evidence indicated that GenX leaders often explicitly state their desire to care for their teachers in order to support their work/life balance, professional growth and on-going commitment to remaining in the profession. The findings inspired our interest to learn more about the evidence base related to leader care and specifically wellbeing and satisfaction.

Global Cities. Global cities [15] are identified and celebrated as powerful international epicenters of influence $[15,16]$. They are now also annually ranked by their economic, social, entertainment, and cultural influence [16]. From our educational vantage point, cities often serve as central nodes of education policy and practice innovation and have catalyzed global teaching, learning, and leadership trends. For example, Chicago [82-84], New York [85,86], London $[87,88]$, and Shanghai $[89,90]$ have all developed international reputations based on their reform initiatives.

Within education research and policy discourse, city jurisdictions are not without their challenges. Urban centers are often described negatively, with urban contexts discussed in terms of challenge [91], disadvantage [92], and difficult circumstances [93]. Not surprisingly, much academic and policy discussion centers on perceived and actual city-based challenges in addressing socio-economic inequality and escalating improvements and opportunities for all students.

In many cities, one of the most pressing urban educational issues relates directly to teacher recruitment and retention [94-96]. Teacher recruitment challenges are often linked to fit [97], geography [98], wages [99], and working conditions [100]. Retention obstacles tend to be tied to teacher education [101] and job dissatisfaction linked to student discipline, motivation, and school administration [102]. These factors fuel, or are fueled by, the cyclical challenges facing city-based educational improvement efforts: the ongoing struggle to create sustained improvement momentum while working to stabilize high volumes of staff turnover [103]. Teacher workforce instability also creates knock-on effects higher up the career ladder. As a result, many cities may also struggle with recruiting school leaders related, but not limited, to teacher apathy about leadership roles [104] and waves of scheduled or early principal retirements [105]. Not surprisingly, high levels of turnover and spiraling attrition rates often inspire upswings in policy and public discussions about the suitability of candidates for the profession, work conditions, and system-level pressures facing education professionals.

\section{Our Overall GCL and School-Based Studies Research Strategy}

\subsection{Overall GCL Project}

The Global City Leaders project was designed to understand more about the experiences, lives, and aspirations of the new generation of school leaders via a three-year mixed qualitative methods 
design involving three city-based policy and practice studies and 12 GenX leader networking events, 125 individual interviews, and nine school-based studies. We began the study by developing city-based studies reflecting local, provincial/state, and national policy and practice [29-32] of educational policy and practice that influence leaders' roles and responsibilities. We recruited city-based cohorts of 20 to 25 GenX principals and vice-principals via invitation emails from our district, organizational, and advisory group contacts. To develop nuanced understandings of GenX leaders, we conducted two annual interviews with each leader. These examined career choices and experiences, professional identities, future ambitions, and possible emerging GenX leadership model(s). All 120 interviews were recorded and fully transcribed using Dedoose (an online cloud-based encrypted qualitative analysis program) to employ a multi-staged coding process and structure [106,107]. Transcripts were analyzed using full-grounded theory approach [28], which resulted in, for example, an application of 25,000 codes across the 65 interviews conducted in the first year [106]. The first- and second-year findings have been reported in our research reports $[17,19,96]$.

Our analysis of 60 first-year principal and vice-principal interviews [17] identified emerging patterns and tensions in leaders' career progression, early leadership experiences, future career aspirations, and life-stage challenges related to starting or having young families [19]. While there are some specific city-based patterns, several trends remain consistent across GenX leaders in all cities including their almost unilateral commitment to and/or interest in improving work/life balance, talent-spotting, capacity-building, and articulating their role in caring for teachers and students [19].

Building on these findings, we conducted a second round of individual interviews and nine school-level studies to learn more about GenX leaders in their own settings. Our light-touch school-level studies examine patterns from our earlier findings in more detail including GenX approaches to school priorities, talent-spotting and recruitment, collaboration, staff-building capacity, and wellbeing and work/life balance. To capture a preliminary snapshot of GenX leadership and how leaders and teachers experienced city-based school-level processes and practices, we used a stratified list of principal participants and phases (elementary, secondary, other) to randomly select three schools per city. The school-level studies engaged at least one school leader and up to six teachers in individual interviews and, in one school, focus groups.

\subsection{School-Based Studies: Data Sources and Collection Process}

This paper draws exclusively from our nine school-based studies of GenX leadership, three each from London, New York City, and Toronto. These studies provide a small preliminary snapshot into how GenX principals were approaching leadership in their schools. The interviews explored how leaders and a small sample of teachers in each school experienced and interpreted their school's approach to the major themes arising from our GenX leader interviews. These included school priorities, collaboration, talent-spotting, building teaching capacity, and wellbeing. This paper draws on our analysis of teacher and leader responses to the suite of questions related to leader caring, including: Is it the role of a leader to care for their staff? Do you feel cared for? Does care play a role in your ability to improve as a teacher? Does care play a role in improving teaching and learning? Do you feel supported?

We created a city-based list of participating principals organized by primary, middle (where appropriate), and secondary phases. We also attempted to plot schools geographically. Across all cities, all principals agreed to participate on first invitation. Principals provided formal administrative consent, after which an electronic information package with instructions and consent information was delivered for communication with all teachers in the school. Teachers were asked to directly email the research team to schedule their interviews. Where this process did not work, a non-leadership team member in the school maintained a confidential roster of participants, upholding their anonymity, from senior school leaders. The need for anonymity was reiterated at each step of the recruitment process and with each individual involved. 
School visits were between half to three-quarters of a day long and involved at least two research team members. Individual interviews were 35-40 min for teachers and 45-60 min for leaders. All participants signed the appropriate consent forms before beginning the interview. While data collection was intended to be exclusively conducted via individual interview, in one school, as requested by the teaching staff, three focus groups were conducted.

\subsection{School-Based Studies: Data Analysis}

Each interview and focus group was fully transcribed by a member of our team and uploaded into Dedoose. We applied a grounded theory approach for the analysis [28] and adopted a three-phase coding structure from the evidence in three phases. In phase one, we grouped the transcripts by school and developed a high-level coding structure representing each of the five topics from the interview instrument: school priorities, collaboration, talent-spotting, building teaching capacity, and wellbeing. Three members of our research team each individually analyzed three leader and three teacher interviews representing a cross-section of schools and cities. This process supported the development of our preliminary list of sub-codes under each of the main headings. As the analysis proceeded, the original coding structure was altered slightly to account for newly recognized themes.

For example, our review of wellbeing-related discussions from across all transcripts generated six sub-codes representing how leaders and teachers discuss their experience of, desire for, and understanding of wellbeing in their lives within and beyond school. The refined wellbeing codes included personal understanding/seeking of wellbeing, personal satisfaction with level of work/life balance, leader role in tending to wellbeing, strategies leaders use to support wellbeing, influence of wellbeing on practice, and work/life balance role models. To refine our analysis, each individual transcript was then reanalyzed by applying the overall coding framework, with team members working in tandem to assess and reinforce their inter-rater reliability and build our ongoing collective cross-city understanding of the findings.

Phase one highlighted that all nine leaders and most of the 54 teachers consistently articulated their belief that leaders should have and take responsibility for caring for their staff. Based on this evidence, we focused our attention on comprehending more about leader and teacher understanding and expectations of teacher wellbeing. During phase two, we revisited our analysis and specifically reexamined all coded data that related to one specific wellbeing-focused research question: Is it $a$ leader's role to care for his or her teachers? As such, all evidence related to leader care, leader support of wellbeing, and leader actions that facilitated teacher perception of support and wellbeing were reexamined and more finely examined.

To further explore this wellbeing-focused research question, we conducted a third phase of analysis and revisited each individual school-level study. We conducted a meta-analysis across all nine schools by examining the key themes emerging from the wellbeing data. We tabulated responses from all leaders across each city and then again across cities. We followed a similar format for teacher interview evidence. From this analysis we identified overarching patterns in leader and teacher responses. For instance, some teachers spoke about being supported by leaders who were committed to being approachable; others gave examples of leaders being understanding. In the findings section, we highlight the specific patterns in how both leaders and teachers discuss care.

We are acutely aware of the small scale of the evidence base and that it is drawn from three different cities with three very different policy and leadership contexts. We reviewed the data by city to identify any city-based patterns or differences in leader and teacher responses. While we anticipated between-city differences reflecting the vastly different policy and social contexts of the education systems, we found little between-city variation in leader or teacher interpretations or expectations. For this reason, we present our analysis in aggregate form across the nine schools. We do not differentiate by city. 


\subsection{School-Based Studies: Participating Leader and School Demographics}

To adhere to our anonymity requirements, we report participating school and leader details in aggregate within each city. Leader and school characteristics are also reported using approximates to ensure anonymity. In New York City, school studies were conducted at one middle and two elementary schools in the socio-economically different areas of Brooklyn and Queens. The schools educate between 500 and 800 students each. Twenty-two teachers participated in data collection. The three leaders, one male and two female, had between two and four years of experience and were aged between 32 and 40 .

In London, three female leaders participated in the study, which represented one elementary, one secondary, and one special school. Leaders had between five and seven years of experience and were between the ages of 29 and 36 at the time of the interview. Schools varied in size from approximately 150 to 400 students and were located in different areas of London. One school was in the early phase of start-up and was significantly smaller, with fewer staff members. As a result, only 15 teachers participated in interviews in London.

In Toronto, the three state-funded participating schools were located in the inner city and in Scarborough and represented both Catholic and non-Catholic school systems. One elementary and two secondary schools were included in the sample. School size varied from approximately 700 to 1,800 students. One female and two male leaders with between six and nine years of experience and between the ages of 38 and 41 were interviewed. Nineteen teachers in total participated in interviews.

\section{Findings}

In one of the most poignant patterns emerging from the evidence, leaders and teachers consistently discuss a very personal interpretation of supportive leader actions most frequently associated with understanding teachers as people with lives outside of school that will, at times, influence their experiences and aspirations within the school. Consistently throughout the data, leaders and teachers discuss their own interpretation of the importance of providing individualized support. We present each of the four original themes emerging from the interviews. These four themes are about leadership actions that have important impact on such variables as collective teacher efficacy and teacher commitment populated on the Emotional Path [27]. These leadership actions can be described as: leader support and understanding; leader approachability; leader knowledge of teachers' personal lives (teacher only); leader modeling of balance between work and life (teacher only). These themes are presented in relative order of importance measured by the frequency of comments by both teachers and leaders. Within each section, we also share leaders' and teachers' thoughts and examples in their own words. We begin by exploring leaders' views followed by the teachers' thoughts on the same theme. However, in some cases, where only teachers highlight the topic, leaders' comments are by nature absent. In the discussion, we highlight some of the differences between leader and teacher views and propose future lines of research and policy actions to support the development of knowledge and practice in the field.

\subsection{GenX Leaders Providing Support and Understanding}

Leaders most frequently discuss their efforts to demonstrate and prioritize care for their teachers as being supportive and understanding. Their commitment to explicitly caring for staff members appears inextricably linked to their desire to support and retain teachers, address issues of work/life balance, and promote workplace satisfaction. Similarly, teachers describe leaders' desire to be supportive and understanding as the most important element of their caring.

\subsubsection{Leaders' Perspectives on Support and Understanding}

When examining how GenX leaders discuss their care for and understanding of their staff members, six categories emerged from our original analysis: nurturing support for each other; focusing on wellbeing; being flexible/allowing time off; understanding individual needs; supporting new staff; 
and including families in school-based events. Leaders consistently articulate their belief in the relationship between caring for staff, making staff feel supported, and their overall happiness and successful students. As one Toronto principal explains:

It's my role to look out for what is best for kids but I also look out for my staff. I think that's one thing that the majority of staff will be able to say unequivocally—-that I will go to bat for them, that I will support them. So, is it my role to care about staff? Kids do come first but I do think that in order to make kids more successful you need a happy staff, or at least a staff that feels valued.

Leaders also express their concern and constructive efforts to support their teachers' work/life balance. Across all schools, leaders articulate their aspirations for their teaching staff to have healthy lives beyond school. Leaders provide examples of their rationale and actions. One leader from New York City describes:

My teachers can't be healthy, good, strong teachers every day for our children if they don't have a work/life balance. [If] you don't have a solid work/life balance then you're not going to be able to give your all when you're here. You're not going to be able to give everything you have to the kids. You're going to get burned out.

Leaders often, frustratingly, experience teacher resistance to adopting more balanced approaches to managing their work lives. Obstacles include teachers' own perceptions of work requirements resulting from peer and external accountability-driven pressures. According to one New York-based principal: "As a leader there's only so much I can do. I can't go home with [my teachers] and force [them] to not work." Leaders recognize the influence external accountability and policy demands have on teachers' perceptions of what is required and the pressure this creates on teachers, leaders, and schools. One London leader explains the challenge of trying to assume a mediating role between policy and accountability pressures and teacher wellbeing:

If [teachers] felt under pressure and monitored all the time, they wouldn't want to be here and that wouldn't get the best out of them. But that's not [the message] I'm getting from the Ofsted framework, which is: "I should be monitoring them all the time and they should all be consistently doing 'this'." And I should have proof that I've monitored them three times every week or whatever it is.

\subsubsection{Teachers' Perspectives on Leaders' Support and Understanding}

Teachers across our school-based studies articulate their belief that leaders need to be supportive and understanding. Teachers appreciate when leaders recognize their individual needs, commitments to their families, and lives beyond school. From teachers' perspectives, leaders' acknowledgement of the personal lives of teachers should extend from their ongoing family commitments to isolated emergencies. This recognition was viewed most highly of all by teachers. One teacher in New York City describes how current leaders' support influences their own work and experience as an educator. More specifically, they share how the leader's own role as a parent creates understanding and support for other educators with children:

Because he has his own life and his own children, I feel like he is considerate. I feel he is able to understand more because he has children. Even if he didn't have children, I think he would understand, too, because that's his personality. He's very easygoing. He's very nice.

Teachers express how understanding is often linked, in schools, to simply being a person and for leaders to be willing to put themselves in others' places. One Toronto teacher shares: "[Our leader] is very human in a sense that if you're not feeling well, she's very understanding. If your child has something going on she's very understanding. That's a really big thing for leaders to have- - that human part." Another teacher explains how fairness and consistency relate to support: 
A leader should definitely have empathy and understand where people are coming from. They need to be fair, and be across the board, if this is the policy it's for everybody. There are no favorites. They need to understand that we have lives as well and that sometimes we need to take off to go to the doctor. Principals can be on you every day, for silly things that don't have to do with teaching. Here it's not like that, which is nice.

Teachers also discuss leaders' roles in supporting work/life balance and acknowledging that teachers have lives beyond the school gates. Teachers link this support and acknowledgement to their motivation and wellbeing. One Toronto teacher shares:

[Our leaders] get it. They know you're busy. They know that school is not everything. They know that a happy YOU is a happy teacher. If I'm able to do the things that make me happy outside of school...that's going to make me a better teacher inside of school. [Our leaders] recognize that.

Teachers openly link support for work/life balance to school-level resourcing and the allocation of resources and support to ensure that teachers can have lives beyond school. One New York-based teacher shares:

Part of [the leader's] job is to make sure that we have what we need. In [that] sense, that we have what we need to do [our job so] that not so much [work] is coming home with us so we CAN have a home life. [It is a leader's job to support making sure] your work life is your work life and it doesn't overlap or infringe on your personal life. If [the leader] has those resources, then [the leader] does have some responsibility for that.

\subsection{GenX Leaders and Approachability}

After support and understanding, approachability is most frequently discussed by leaders as being core to their care for teachers. Leaders describe their own personal approachability-focused actions as: having difficult improvement-oriented conversations; treating staff members like family/community; being present/having open-door policies; and having a positive attitude. Leaders provide examples of how they create safe spaces for staff members to interact, and to resolve conflicts by having honest conversations and taking explicit steps to develop trust among staff and between teachers and their leadership teams.

\subsubsection{Leaders' Perspectives on Approachability}

Most leaders state it is their desire and responsibility for teachers to feel they are approachable for both personal and professional discussions. Leaders repeatedly link approachability to their role in supporting teachers to develop as professionals and being available for purely supportive but also challenging conversations. As one principal from New York says:

Caring to me means not just doing whatever [teachers] want or giving them whatever they want, or being the ear to them whenever they want, but also sitting down with them and saying: "Because I care for you, and I want to change this reputation that you have at this school, what steps are we going to take to make that happen? Who can we bring in to support you?" [It is saying:] "I want you to be successful as a teacher and we've run into some obstacles. It's in both of our best interests-and certainly for the kids' best interests-for us to make some changes." So "caring for" is not always being a shoulder to cry on.

Leaders are acutely aware of the need for and challenges associated with difficult conversations. However, they rest much of their discussion of approachability on their willingness to be there for staff consistently, as one London leader describes: 
It is funny that teachers have difficulty with [hard conversations] because they do it all the time with children. [They] have difficult conversations 100 times a day. When you have to have a difficult conversation with an adult, people feel sick, worry about it, people cry. It's quite strange because they spend 10 times as much time worrying about it than if they just did it. I'm as guilty of it as everyone else. But I think raising your self-awareness about it is really important. It's not something that's solvable overnight. That's the kind of thing that leads to people feeling fulfilled at work because they get feedback. People say "thank you." People appreciate it. Otherwise, people just hide away and it's quite difficult.

\subsubsection{Teachers' Perspectives on Approachability}

Teachers echo leaders' views that leaders' approachability [16] is a key factor in demonstrating their support for teachers and enacting an ethic of care. Approachable leaders have open-door policies and take actions that make teachers feel comfortable talking to them. Teachers also state that leaders need to demonstrate that they are personable and there to support teachers when needed. One teacher describes approachability as the leader's availability for conversations and meaningful developmental discussions. Leaders also need to be real people and not just business-like managers, as one London teacher describes: "[Leaders] need an approachable head and someone who is a bit more of a public face. You need someone who isn't just a business side." A New York leader adds:

The administration here, to their credit, is very personable. I can go have a conversation and be quite frank and honest with them if I'm having a difficult time with something, or I have an idea, or I want to have a learning opportunity. All three of them are fantastic; they're willing to offer insight, they're willing to provide opportunities, so that's really nice.

Support during times of difficulty is also a key element of how teachers frame a leader's approachability. Teachers suggest that leaders need to be willing to reach out and solicit approaches from teachers. One London teacher shares this experience and its influence:

I had a particularly bad experience at a parents' evening and I was quite upset about it. The deputy head, who was my mentor at the time, actually texted me afterwards and said "I hope you're okay. We can talk about it. Don't worry. It's not a reflection on you." That was really nice as well because you felt like actually someone did really care.

\subsection{GenX Leaders' Understanding and Knowledge of Teachers' Personal Lives (Teachers Only)}

While not highlighted by leaders, teachers consistently feel their leaders need to have some knowledge of their lives and experience to truly understand and support them. As one New York teacher explains:

It's not like I expect the principal to know everything that's going on in my life. But I think he or she should be visible [and] should be interacting with the teachers and the students, so that they know more about what's going on in your classroom and maybe a little bit about what's going on in your life.

Teachers share why leaders need deep knowledge of their teachers, the strategies leaders can adopt to build that knowledge, and the potential outcomes associated with understanding the people in the school. As one Toronto teacher explains:

[Leaders] have to get to know your staff. You have to get to know them on a personal level. I think that's really, really important because the school CANNOT run from the office down. In order to facilitate that, [leaders] need to know what's going on in their famil[ies]...drop by their office[s] [and] swing by their classroom[s]. If they're going through personal issues, [teachers] need to know you're there to talk with. All those little things pay off in dividends later, not only for the staff but for the students in the building. 
Again, teachers are aware that knowledge and personal connections are not just about good times but also difficult conversations and development. One Toronto teacher shares:

I think some principals are very good at getting to know their staff, and able to make that personal connection, and I think that that goes a long way with people. Feeling that they are cared about, that the principal takes an interest in me and what my life is about. I think also that caring about people sometimes means tough love as well.

\subsection{GenX Leaders' Modeling of Balance between Work and Life: Serving as Appropriate Role Models (Teachers Only)}

Teachers discuss the importance of developing and maintaining a healthy work/life balance. Teachers highlight the important role that their school leaders play in supporting and modeling a healthy balance for staff. Often, a leader's modeling of work/life balance or related behaviors seems to be much more influential than simple statements or encouragement by leaders. One Toronto teacher explains:

Seeing that [leaders] don't work ridiculous hours makes you think: "actually it's okay to go home early occasionally or some days." It's not looked down on if you leave at 4 . I know at some schools, some people think: "Well why are you leaving, it's not okay." I try once a week to leave around 4 o'clock. I [can] actually do something productive that evening and not be tired. I've seen that they don't work crazy hours. It's reassuring.

A London teacher also echoes the importance of leaders' modeling work/life balance:

The senior leadership team-they're here at 8; they leave [at] 5, 5.30, maybe 6. They lead by example. My mentor will make sure that I'm not working too much at my weekends just by asking: "I hope you're not doing too much? We don't want you to be doing that much. If you're not managing to do all your work in the given time then we need to think about how we can achieve that."

In a rare and powerful statement of support for a leadership team that is actively modeling work/life balance, one London leader from a different school shares:

I get the impression that [our] leadership seemed to have nailed it in terms of work/life balance. They always leave in great time, clearly cause they're organized and they're on top of everything. Maybe they're taking work home with them-I don't know. But it's a very nice attitude they have towards telling all of us that we should leave, too. We're all working hard. They're [saying]: "You really should go home, you shouldn't be here, go, go, go." You're encouraged not to be here after work. But because of the kind of teachers who we are, I suppose we want to stay and get everything done, so we're usually kicked out. There's a group of us teachers who get kicked out of school every day [at] quarter [to] six when the cleaners lock up. We're not work[ing] so hard that we have no life. They've got that side of it right.

\section{Discussion and Conclusions}

The core purpose of this paper is to add evidentiary flesh to the bones of the increasingly accepted strand of sociology-generations at work-by focusing on leaders' care. Our larger research from which the evidence for this paper was drawn establishes patterns in how members of different generations approach, design, and balance their work and personal lives. As little research has been conducted related to generational work and schools, we also seek to explore if, and how, generational theory holds true within schools and school city systems. Our intention has always been to understand more about GenerationX leaders' career, lives, leadership and aspirations in the hope that this knowledge will support leaders and policymakers in providing the support and 
challenge required to recruit, develop and retain leadership talent. In this paper, we draw from nine school-level studies across London, New York City and Toronto to explore a very narrow strand of evidence to examine more specifically how GenX leaders and their teachers conceptualize and articulate leaders' roles in caring for their teachers.

Within- and cross-school and city analyses consistently highlighted how GenX leaders across all three cities explicitly discuss their sense of responsibility for caring for their teachers both professionally and personally. Leader and teacher discussions consistently extend beyond a typical best-practice-inspired discussion of leadership roles to a notion of care much more rooted in their own current lived experiences and challenges. Our analysis identified an interesting pattern: leaders' and teachers' discussion related to leader care for their staff and how care is enacted fit neatly into the aforementioned Emotional Path of influence [27]. We found a high level of agreement between leaders and teachers across London, New York City, and Toronto in terms of how leaders are and should be actively demonstrating care for teachers. More specifically, teachers and leaders interpret leader care as focusing on providing individualized support via support and understanding and approachability. Teachers solely focus on a third theme within individualized support: leader knowledge and understanding of teachers' personal lives. Finally, teachers also identify a second, separate, element of TCE as important: leaders being a good role model. Interestingly, teachers almost exclusively focus on leaders as role models of work/life balance which provides an interesting twist on more work-related conceptions of role modeling.

Across the three cities, leaders articulate their belief that tending to their teachers' feelings and dispositions is an important element of their work. Leaders describe the motivations behind their care-based intentions and actions supporting teacher wellbeing, happiness at work, sense of safety and commitment to the school. Leaders' comments almost always seem poised within discussions of wanting teachers to teach well and develop but also remain in the profession. However, within Toronto, discussions of teacher retention were muted due to the climate of relative consistency which, in recent history, ensures a relatively stable teacher number. Leader views echo wider research findings linking leader behavior and prioritization of work/life balance to job satisfaction, support and organizational loyalty [43-45]. Similarly, leader enactment of transformational leadership focused on building CTE positively influences employee satisfaction, reduced stress levels, improved wellbeing [46] and collective efficacy [47].

Teachers echo leader sentiments on the first two leadership actions effective in improving CTE and added a third individualized support strategy that was not discussed by leaders: leader knowledge and understanding of teachers' personal lives. Teachers express their desire for individualized relationships with their school leaders and a recognition that, as people, they have busy and demanding lives beyond the school gates as well. This priority did not overshadow their commitment to their schools and teaching but marked an explicit statement of the importance of leader recognition of teacher wellbeing and work/life balance beyond the school. Teachers often hinted at an underlying desire to feel trusted enough by leaders to make independent decisions about the balance between their teaching, school and family when the need occurred. Again, the strength of leader-teacher relationships appears to be an important factor in teacher satisfaction and intention to remain [42].

In discussing wellbeing more generally, teachers articulate their experience with leaders working to support them and encouraging them to support each other. Teachers express a clear sense of the influence of leader commitment to teachers collectively influences their practice and general wellbeing. Teachers describe how a positive school environment is fostered through collaboration and supported by the school leaders. One teacher explains the influence of leader care on collaboration: "There's a massive emphasis on working together, and we're all moving towards the same goals and targets, and there's no point in working against each other." Another teacher describes how teachers are inspired to support each other: "Everyone kind of pulls together and everyone works hard. It doesn't mean we're plucking off at 3:00 or 4:00. You've got to be prepared for the hours but I think everyone's wellbeing is looked after by each other..." Perhaps this is not surprising given the GenX prioritization of 
workplace relationships and collaboration, and the high value GenX more widely places on work-based relationships and relationships with organizational peers.

Teachers also exclusively discuss the need for leaders to be good work/life balance role models. Teachers consistently suggest their leaders care for teacher wellbeing; however, many also comment that leaders also need to role model by taking care of themselves. Leaders did not highlight role modeling self-care or work/life balance as part of their caring for teachers. This may be related to GenX leaders' lack of their own work/life balance role models [12]. This may also speak to GenXers' interest in blending work and life and their own stated struggles to find work/life balance. Almost all leaders in the overall study struggle to find balance between their jobs and lives [12]. Some leaders also share how they are lacking work/life role models-other school leaders who are successful in their leadership roles and have lives that make them happy beyond work. As GenXers are known for the central place of-or at least the quest for-work/life balance in their lives [12], it is perhaps not surprising that our participating leaders have taken clear and deliberate steps to encourage teacher work/life balance, even if they continue to struggle with their own. As many GenX principals also explicitly state, they have not worked with or observed principals who serve as role models for their own healthy work/life balance [12], and thus teacher desire for leaders to be role models may reflect these underlying tensions.

\subsection{GenX Leadership: Mediating the Influence of City-Based Structures and Systems}

Our GCL city-based policy studies [29-32] illustrate that leaders in each city work in radically different policy and practice contexts. For example, London leaders retain greater responsibility for staffing, finance, and school outcomes than leaders in Toronto. The overall structures of the education systems are also vastly different. Toronto and New York City have strong districts and layers of administrative support for school leaders when compared to London, where many schools work beyond structural support from local authorities, often in relative isolation. Finally, the high-stakes nature of accountability varies across the three cities, with London schools inspected by an external body (Ofsted) and publically ranked according to student test scores. New York leaders work within a similar but slightly less pressurized climate. Ontario has less frequent and less high-stakes student testing and a more continuous improvement-oriented system. Each of these structural configurations creates different pressures on the role of school leader; we anticipated that there would be a notable difference in how leaders discuss care and their overall role in working for and with teachers.

Perhaps the most surprising element of our school-based findings is that, even within radically different contextual environments that create vastly different leadership pressures and legal relationships between leaders and teachers, leaders and teachers did not differ across contexts in their belief in leaders' duty, ability, and commitment to care for teachers. The prioritization of people, support, being human, and striving for balance between work and life remains central. We are acutely aware of the small size of the sample; however, our early findings may in fact reinforce the importance of the role of school leaders in buffering their schools and staff members from external factors. This contributes to a growing body of literature examining comparative approaches [45] and studies [46] examining school leadership in different contexts.

If our study had simply been conducted in one city, we would not have been able to identify cross-jurisdictional patterns and differences, and this could have radically influenced our ability to understand the role and experience of leaders. Similarly, our findings highlight the importance of understanding how leaders in different jurisdictions need to work in order to support, buffer, and retain their teachers. While there is a consistent message that leaders need to be supportive and approachable, we believe there may be other actions that leaders can take to support teachers, and these will be different in different cities. For example, do the nuances of leader approachability look different in a context where leaders hire, compensate with performance-based pay, and fire teachers (i.e., London) versus those where most human-resource-related functions are held centrally by districts and school boards? We will continue to explore these issues in our larger GCL analysis. 
One of the reasons for considering leader care and the generational and international implications of the pathways is the need to consider the wider school-level social considerations that influence a leader's ability and willingness to care for his or her teachers. Similarly, we provide preliminary evidence from a small set of participants, showing that the actual context within which schools operate may not influence their perception of the role of leaders in caring for staff members. This, in turn, clearly points to the different challenges leaders face in mediating external environmental challenges in caring for teachers.

\subsection{Future Research and Policy Implications}

While there are pockets of change, the accountability and standards movement shows little hope of slowing down, and leaders in our three cities report increasing workload pressures in their GCL interviews. For leaders, the volume of reporting, testing, and inspection differs according to the overarching structure of the education system. Based on our evidence, work/life-related issues will continue to be important and may even become one of the bigger concerns facing leaders directly over the coming years. As the emerging generation of leaders is predisposed to seeking work/life balance, the inherent tensions may become more apparent. GenXers have been widely observed leaving jobs and professions that do not allow them to achieve their sought-after balance between work and life. For this reason alone, additional research and, in turn, policy considerations of the implications of workload and work/life balance on leadership recruitment, enactment, and retention will become even more important in global cities and beyond.

This is potentially very worrying to those policy and practice leaders working to recruit and retain city-based school leaders. There is a growing need for research and development strategies to address the structural conditions of leaders' work that challenge work/life balance and their own ability to articulate and act on their work/life-balance goals. More importantly, these preliminary findings from our school-based studies suggest that selection, training, and development for this next generation of leaders should include and focus on nurturing the knowledge, skills, understandings, and attributes that leaders need to address work/life balance for leaders and teachers. GenXers and their GenY colleagues will only become more committed to pursuing balance as they get older. Teachers in our study clearly state how leaders can support their work/life balance needs, and we believe there is an urgent need to build on this evidence base and create innovative strategies for leaders to assist their teachers while maintaining all current school-level objectives. Our findings perhaps indicate the urgent and important need for policymakers and researchers to reinvigorate their interest and advocacy in support not only of workload, but of work/life balance, research, and development.

\section{Limitations}

The overall Global City Leaders study is conducting preliminary research on a previously unexplored area of research. As such, we are working with a relatively small number of GenX leaders in each city to create a preliminary evidence base upon which to conduct future, more large-scale research. There is equally little research on the school-level perspectives of the overall leadership and organization of schools by GenX leaders. Our nine school-level studies are intended to make a small, early contribution to buttress our self-reported leader data with teacher views on the leadership and the lives of schools and teachers. The propositions set forth, specifically around the prominence of desires for leaders to know and care for people beyond school as well as the needs for leaders themselves to serve as work/life role models will be tested in future research by our team and others.

Our team had previously attributed the rise in leader discussions of work/life balance, collaboration, and the importance of school-based relationships $[97,98]$ to three potentially influential factors: (1) GenX leaders' expression of generationally attributed work-related characteristics [12]; (2) GenX leaders own life course issues with work/life given their caring roles for children and/or parents at home; and (3) a growing chorus of policy, practice, and union leaders highlighting the challenges associated with current school-level professional workloads and workplace conditions. 
The convergence of these issues creates an interesting opportunity to gather evidence and reflect on the notion of leadership and care within a small number of schools in three very different policy and practice contexts. However, we are also aware of the challenge it creates in establishing the source and influence of this generation's preoccupation with care.

The characteristics of GenXers in the workplace [12] align closely with current research and thinking about great leadership and the knowledge, skills, and ability required to improve student outcomes and nurture school-level collaboration, diversity, and innovation [80,81]. However, disaggregating what GenX leaders have learnt and applied from leadership theory from their generational predispositions creates evidentiary and analytical challenges. There remains a question related to if GenX leaders' leadership actions are driven by their own generational predispositions or current evidence on what constitutes instructionally meaningful leadership.

The evidence emerging from this paper appears to indicate that both teachers and leaders are committed to and expect leaders to have a deep personal understanding and appreciation for staff members' outside-of-school lives. Much of the research in this area has consistently focused on within-school and work-related elements of care. Again, this is difficult to associate solely with generational attributes and approaches. However, it does suggest an important line of future research related to both differences between generations and, more widely, differences between municipal or national jurisdictions.

Our Global City Leaders project, including the evidence presented here, focuses on understanding more about the emerging generation of leaders and their approach to their careers, leadership roles and personal lives. We do not explicitly set up our findings to juxtapose GenX and boomer leaders for several reasons, including the complexity of the task required to conduct an international, cross-generational study. Second, we believe much of the current educational leadership research canon has been influenced by the experience of older, and consequently more experienced leaders, thus negating the influence that generation, specifically a younger generation, may have on leadership careers, leadership and aspirations.

Acknowledgments: The authors wish to thank the ESRC (RES-061-25-0532) for their funding of the Young Global City Leaders project. We would also like to thank our Advisory Group members, participants and research team colleagues Paul Armstrong, Helen Green, and Kerrie Kennedy for their contributions to the project. Finally, the authors would like to thank the editors and reviewers for their thoughtful and detailed comments.

Author Contributions: Karen Edge is the principal investigator of the GCL study and the primary author of this paper. Katherine Descours and Keren Frayman serve as researchers on the study and were engaged in the design, gathering (Descours only), analysis of the evidence, and writing of this manuscript.

Conflicts of Interest: The authors declare no conflict of interest.

\section{References}

1. Hodgkinson, C. Educational Leadership: The Moral Art; SUNY Press: Albany, NY, USA, 1991.

2. Noddings, N. The Challenge to Care in Schools; Teachers College Press: New York, NY, USA, 2005.

3. Duke, D. Caring Safe Schools for All Children; Allyn and Bacon: Boston, MA, USA, 2000.

4. Beck, L.J. Reclaiming Educational Administration as a Caring Profession; Teachers College Press: New York, NY, USA, 1994.

5. Louise, K.S.; Murphy, J.; Smylie, M. Caring leadership in schools: Findings from exploratory analyses. Educ. Admin. Q. 2016. [CrossRef]

6. Gabriel, Y. The caring leader-What followers expect of their leaders and why? Leadership 2015, 11, 316-334. [CrossRef]

7. Berl, P. Crossing the generational divide: Supporting generational differences at work. Exch. Early Child. Leaders Mag. 2006, 168, 73-78.

8. Zemke, R.; Raines, C.; Filipczak, B. Generations at Work: Managing the Clash of Veterans, Boomers, Xers, and Nexters in Your Workplace; AMA Publications: New York, NY, USA, 2000.

9. Smola, K.; Sutton, C. Generational differences: Revisiting generational work values for the new millennium. J. Organ. Behav. 2002, 23, 363-382. [CrossRef] 
10. Duscher, J.; Cowin, L. Multigenerational nurses in the workplace. J. Nurs. Admin. 2004, 34, 493-501.

11. Kunreuther, F. The changing of the guard: What generational differences tell us about social-change organizations. Nonprofit Volunt. Sector Q. 2003, 32, 450-457. [CrossRef]

12. Edge, K. A review of the empirical generations at work research: Implications for school leaders and future research. Sch. Leadersh. Manag. 2014, 2, 136-155. [CrossRef]

13. Spillane, J.P.; Lee, L. Novice school principals' sense of ultimate responsibility problems of practice in transitioning to the principal's office. Educ. Admin. Q. 2013, 50, 431-465. [CrossRef]

14. Stone-Johnson, C. Not cut out to be an administrator: Generations, change and the career transition from teacher to principal. Educ. Urban Soc. 2014, 46, 606-625. [CrossRef]

15. Sassen, S. The Global City: New York, London, Tokyo; Princeton University Press: Princeton, NJ, USA, 1991.

16. Amburn, B. The 2008 Global Cities Index. Available online: http://foreignpolicy.com/2009/10/06/the-2008global-cities-index/ (accessed on 31 October 2009).

17. Edge, K.; Amstrong, P.; Descours, K.; Dapper, E.; Horton, J.; Batlle, N. Young Global City Leaders Interviews: Emerging Patterns from London; Institute of Education, University of London: London, UK, 2013.

18. Wilson, S. Caring leadership applied in the classroom to embrace the needs of students. J. Coll. Teach. Learn. 2012, 10, 23-28. [CrossRef]

19. Edge, K.; Armstrong, P.; Descours, K.; Mejias, S.; Batlle, N. Young Global City Leaders Interviews: Emerging Patterns from New York; Institute of Education, University of London: London, UK, 2013.

20. Bubb, S; Earley, P. Managing Teacher Workload: Work-Life Balance and Wellbeing; SAGE: London, UK, 2004.

21. Day, C.; Kington, A. Identity, well-being and effectiveness: The emotional contexts of teaching. Pedag. Cult. Soc. 2008, 16, 7-23. [CrossRef]

22. Day, C. Committed for life? Variations in teachers' work, lives and effectiveness. J. Educ. Chang. 2008, 9, 243-260. [CrossRef]

23. Sackney, L.; Noonan, B.; Miller, C.M. Leadership for educator wellness: An exploratory study. Int. J. Leadersh. Educ. 2000, 3, 41-56. [CrossRef]

24. Devos, G.; Bouckenooghe, D.; Engels, N.; Hotton, G.; Aelterman, A. An assessment of well-being of principals in Flemish primary schools. J. Educ. Admin. 2007, 45, 33-61. [CrossRef]

25. Carr, A. Anxiety and depression among school principals-Warning, Principalship can be hazardous to your health. J. Educ. Admin. 1994, 32, 18-34. [CrossRef]

26. Sun, J.; Leithwood, K. Leadership effects on student learning mediated by teacher emotions. Societies 2015, 5, 566-582. [CrossRef]

27. Leithwood, K.; Patten, S.; Jantzi, D. Testing a conception of how leadership influences student learning. Educ. Admin. Q. 2010, 46, 671-706. [CrossRef]

28. Strauss, A.; Corbin, J. Grounded theory methodology. In Handbook of Qualitative Research; Denzin, N.K., Lincoln, S., Eds.; SAGE Publications, Inc.: Thousand Oaks, CA, USA, 1994; pp. 273-285.

29. Edge, K.; Armstrong, P.; Batlle, N. School Leadership Policy Landscape: Toronto, Ontario; Institute of Education, University of London: London, UK, 2013.

30. Armstrong, P.; Edge, K.; Batlle, N. School Leadership Policy Landscape: London, UK; Institute of Education, University of London: London, UK, 2013.

31. Armstrong, P.; Edge, K.; Batlle, N. School Leader Responsibilities and Accountabilities in London, New York and Toronto; Institute of Education, University of London: London, UK, 2013.

32. Mejias, S.; Edge, K.; Armstrong, P.; Batlle, N. School Leadership Policy Landscape: New York City, USA; Institute of Education, University of London: London, UK, 2013.

33. Gilligan, C. In a Different Voice: Psychological Theory and a Women's Development; Harvard University Press: Cambridge, UK, 1982.

34. Noddings, N. Caring: A Feminine Approach to Ethics and Moral Education; University of California Press: Berkeley, CA, USA, 1986.

35. Clawson, J.G. Level Three Leadership: Getting Below the Surface, 4th ed.; Pearson-Prentice Hall: Upper Saddle River, NJ, USA, 2009.

36. Hargreaves, A. The emotional practice of teaching. Teach. Teach. Educ. 1998, 14, 835-854. [CrossRef]

37. Jingping, S.; Leithwood, K. Direction-setting school leadership practices: A meta-analytical review of evidence about their influence. Sch. Effect. Sch. Improv. 2015, 26, 499-523. 
38. Klinker, J.F.; Hackmann, D.G. An Analysis of Principals' Ethical Decision Making using Rest's Four Component Model of Moral Behavior. J. Sch. Leadersh. 2004, 14, 434-455.

39. Zaretsky, L. Advocacy and administration: From conflict to collaboration. J. Educ. Admin. 2004, 42, $270-286$. [CrossRef]

40. Ciulla, J.B. Leadership and the ethics of care. J. Bus. Ethics 2009, 88, 3-4. [CrossRef]

41. Simola, S.K.; Barling, J.; Turner, N. Transformational leadership and leader moral orientation: Contrasting an ethic of justice and an ethic of care. Leadersh. Q. 2010, 21, 179-188. [CrossRef]

42. Müller, K.; Alliata, R.; Benninghoff, F. Attracting and retaining teachers: A question of motivation. Educ. Manag. Admin. Leadersh. 2009, 37, 574-599. [CrossRef]

43. Lambert, S.J. Added benefits: The link between work-life benefits and organizational citizenship behavior. Acad. Manag. J. 2000, 43, 801-815. [CrossRef]

44. Forsyth, S.; Polzer-Debruyne, A. The organisational pay-offs for perceived work-life balance support. Asia Pac. J. Hum. Resour. 2007, 45, 113-123. [CrossRef]

45. Renee Baptiste, N. Tightening the link between employee wellbeing at work and performance: A new dimension for HRM. Manag. Decis. 2008, 46, 284-309. [CrossRef]

46. Skakon, J.; Nielsen, K.; Borg, V.; Guzman, J. Are leaders' well-being, behaviours and style associated with the affective well-being of their employees? A systematic review of three decades of research. Work Stress 2010, 24, 107-139. [CrossRef]

47. Nielsen, K.; Munir, F. How do transformational leaders influence followers' affective well-being? Exploring the mediating role of self-efficacy. Work Stress 2009, 23, 313-329. [CrossRef]

48. Bass, B. Two decades of research and development in transformational leadership. Eur. J. Work Organ. Psychol. 1999, 8, 9-32. [CrossRef]

49. Arnold, K.; Turner, N.; Barling, J.; Kelloway, K.; McKee, M. Transformational leadership and psychological well-being: The mediating role of meaningful work. J. Occup. Health Psychol. 2007, 12, 193-203. [CrossRef] [PubMed]

50. Geijsel, F.; Sleegers, P.; Leithwood, K.; Jantzi, D. Transformational leadership effects on teachers' commitment and effort toward school reform. J. Educ. Admin. 2003, 41, 228-256. [CrossRef]

51. Leithwood, K.; Jantzi, D. The relative effects of principal and teacher sources of leadership on student engagement with school. Educ. Admin. Q. 1999, 35, 679-706. [CrossRef]

52. Bass, B.M.; Avolio, B.J. Transformational leadership and organizational culture. Int. J. Public Admin. 1994, 17, 541-554. [CrossRef]

53. Yukl, G. Leadership in Organizations; Prentice Hall: Upper Saddle River, NJ, USA, 2002.

54. Evans, L. Delving deeper into morale, job satisfaction and motivation among education professionals: Re-examining the leadership dimension. Educ. Manag. Admin. 2001, 29, 291-306. [CrossRef]

55. Thompson, D.; McNamara, J.; Hoyle, J. Job satisfaction in educational organizations: A synthesis of research findings. Educ. Admin. Q. 1997, 33, 7-37. [CrossRef]

56. Edmunds, J.; Turner, B.S. Generations, Culture and Society; Open University Press: Buckingham, UK, 2002.

57. Pilcher, J. Mannheim's sociology of generations: An undervalued legacy. Br. J. Sociol. 1994, 45, 449-481. [CrossRef]

58. Edmunds, J.; Turner, B.S. Global generations: Social change in the twentieth century. Br. J. Sociol. 2005, 56, 559-577. [CrossRef] [PubMed]

59. Gentry, W.A.; Griggs, T.L.; Deal, J.J.; Mondore, S.P.; Cox, B.D. A comparison of generational differences in endorsement of leadership practices with actual leadership skill level. Consult. Psychol. J. Pract. Res. 2011, 63, 39-49. [CrossRef]

60. Cogshall, J.G.; Ott, A.; Behrstock, E.; Lasagna, M. Retaining Teacher Talent: The View from Generation Y; Learning Point Associations and Public Agenda: New York, NY, USA, 2010.

61. Espinoza, C.; Ukleja, M.; Rusch, C. Managing Millennials: Discover the Core Competencies for Managing Today's Workforce; Wiley: Hoboken, NJ, USA, 2010.

62. Gursoy, D.; Maier, T.; Chi, C. Generational differences: An examination of work values and generational gaps in the hospitality workforce. Int. J. Hosp. Manag. 2008, 27, 448-458. [CrossRef]

63. Hewlett, S.A.; Sherbin, L.; Sumberg, K. How Gen Y and Boomers will reshape your agenda. Harvard Bus. Rev. $2009,87,71-76$. 
64. Pham, V.; Miyake, L.; Case, J.; Gil, S. The Gen Y Perceptions Study. Available online: http://www. spectrumknowledge.com/img/Gen_Y_Perception_Study_CREW_Final.pdf (accessed on 2 December 2012).

65. Bulman, R. Teachers in the "hood": Hollywood's middle-class fantasy. Urban Rev. 2002, 34, 251-276. [CrossRef]

66. Coggshall, J.; Behrstock-Sherratt, E.; Drill, K. Workplaces that Support High-Performing Teaching and Learning: Insights from Generation Y Teachers; American Federation of Teachers and American Institutes of Research: Washington, DC, USA, 2011.

67. Johnson, S.M. Finders and Keepers: Helping New Teachers Survive and Thrive in Our Schools; Jossey-Bass: San Francisco, CA, USA, 2004.

68. Williamson, R.; Meyer-Looze, C. Working with Gen Y Teachers: Dealing with a Changing Teacher Workforce. Available online: http:/ /www.eric.ed.gov/PDFS/ED538402.pdf (accessed on 13 February 2013).

69. Lovely, S.; Buffum, A. Generations at School: Building an Age-Friendly Learning Community; SAGE: London, UK, 2007.

70. Johnson, S.M.; Kardos, S. Bridging the generation gap. Educ. Leadersh. 2005, 62, 8-14.

71. Strauss, W. Talking about their generations: Making sense of a school environment made up of Gen-Xers and Millennials. Sch. Admin. 2005, 62, 10-14.

72. Rinke, C. Exploring the generation gap in urban schools: Generational perspectives in professional learning communities. Educ. Urban Soc. 2009, 42, 3-24. [CrossRef]

73. Walmsely, A. Closing the communication gap. Educ. Horiz. 2011, 90, 25-26.

74. Hess, N.; Jepsen, D. Career stage and generational differences in psychological contracts. Career Dev. Int. 2009, 14, 261-283. [CrossRef]

75. Stone-Johnson, C. Talkin' bout my generation: Boomers, Xers and educational change. J. Educ. Chang. 2011, 12, 221-239. [CrossRef]

76. Salajan, F.; Schonwetter, D.; Cleghorn, B. Student and faculty inter-generational digital divide. Comput. Educ. 2010, 55, 1393-1403. [CrossRef]

77. Worley, K. Educating college students of the net generation. Adult Learn. 2011, 22, 31-39. [CrossRef]

78. Zieglar, S. The (mis)education of generation M. Learn. MediaTechnol. 2007, 32, 69-81. [CrossRef]

79. Day, C.; Sammons, P.; Hopkins, D.; Harris, A.; Leithwood, K.; Gu, Q.; Brown, E.; Ahtaridou, E.; Kington, A. The Impact of School Leadership on Pupil Outcomes; Research Report RR108; Department of Children, Schools and Families: London, UK, 2009.

80. Leithwood, K.; Jantzi, D. Linking leadership to student learning: The contributions of leader efficacy. Educ. Admin. Q. 2008, 44, 496-528. [CrossRef]

81. Robinson, V.; Lloyd, C.; Rowe, K. The impact of leadership on student outcomes: An analysis of the differential effects of leadership types. Educ. Admin. Q. 2008, 44, 635-674. [CrossRef]

82. Bryk, A.S.; Sebring, P.B.; Kerbow, D.; Rollow, S.; Easton, J.Q. Charting Chicago School Reform: Democratic Localism as a Lever for Change; Westview Press: Boulder, CO, USA, 1998.

83. Hess, G.A., Jr. School Restructuring, Chicago Style; Corwin Press: Thousand Oaks, CA, USA, 1991.

84. Wohlstetter, P.; Odden, A. Rethinking school-based management policy and research. Educ. Admin. Q. 1992, 28, 529-549. [CrossRef]

85. Elmore, R.; Burney, D. Investing in Teacher Learning: Staff Development and Instructional Improvement in Community School District \#2, New York City; National Commission on Teaching \& America's Future; Teachers College, Columbia University: New York, NY, USA, 1997.

86. Elmore, R.; Burney, D. Continuous Improvement in Community District \#2; Inter-American Development Bank: New York, NY, USA, 2002.

87. Hargreaves, D. Leadership for Transformation within the London Challenge; Annual Lecture at the London Leadership Centre; Institute of Education: London, UK, 2003.

88. Brighouse, T. The London Challenge-A personal view. In Education in a Global City: Essays from London; Brighouse, T., Fullick, L., Eds.; Institute of Education: London, UK, 2007; pp. 71-94.

89. Vanderklippe, N. What Shanghai Can Teach us about Teaching Math. Available online: http://www.the globeandmail.com/news/national/education/what-shanghai-can-teach-us-about-teaching-math/article178 35021/ ?page=all (accessed on 23 March 2015).

90. Wang, J.; Lin, E. Comparative studies on US and Chinese mathematics learning and the implications for standards-based mathematics teaching reform. Educ. Res. 2005, 34, 3-13. [CrossRef] 
91. Chapman, C. Towards a framework for school-to-school networking in challenging circumstances. Educ. Res. 2008, 50, 403-420. [CrossRef]

92. Smyth, E.; McCoy, S. Investing in Education: Combating Educational Disadvantage; Economic and Social Research Institute (ESRI): Dublin, Ireland, 2009.

93. Harris, A. Effective leadership in schools facing challenging circumstances. Sch. Leadersh. Manag. 2002, 22, 15-27. [CrossRef]

94. Allen, M.B. Eight Questions on Teacher Recruitment and Retention: What Does the Research Say? Education Commission of the States: Denver, CO, USA, 2005.

95. Jacob, B. The challenges of staffing urban schools with effective teachers. Future Child. 2007, 17, 129-154. [CrossRef] [PubMed]

96. Johnson, S.; Berg, J.; Donaldson, M. Who stays in teaching and why: A review of the literature on teacher retention. In The Project on the Next Generation of Teachers; Harvard Graduate School of Education: Boston, MA, USA, 2005.

97. Ballou, D. Do public schools hire the best applicants? Q. J. Econ. 1996, 111, 97-133. [CrossRef]

98. Boyd, D.; Lankford, H.; Loeb, S.; Wyckoff, J. The draw of home: How teachers' preferences for proximity disadvantage urban schools. J. Policy Anal. Manag. 2005, 24, 113-123. [CrossRef]

99. Dolton, P.; van der Klaaw, W. The turnover of teachers: A competing risks explanation. Rev. Econ. Stat. 1999, 81, 543-552. [CrossRef]

100. Hanushek, E.; Kain, J.; Rivkin, S. Why public schools lose teachers. J. Hum. Resour. 2004, 34, $326-354$. [CrossRef]

101. Freedman, S.W.; Appleman, D. In it for the long haul: How teacher education can contribute to teacher retention in high-poverty. Urban Sch. J. Teach. Educ. 2009, 60, 323-337. [CrossRef]

102. Ingersoll, R. Is There Really a Teacher Shortage? A Report Co-Sponsored by the Center for the Study of Teaching and Policy and the Center for Policy Research in Education; University of Washington, Center for the Study of Teaching and Policy: Washington, DC, USA, 2003.

103. McKinney, S.; Berry, R.; Dickerson, D.; Campbell-Whately, G. Addressing urban high-poverty school teacher attrition by addressing urban high-poverty school teacher retention: Why effective teachers persevere. Educ. Res. Rev. 2007, 3, 1-9.

104. Gronn, P.; Lacey, K. Positioning oneself for leadership: Feelings of vulnerability among aspirant principals. Sch. Leadersh. Manag. 2004, 24, 405-424. [CrossRef]

105. Howson, J. The State of the Labour Market for Senior Staff in Schools in England and Wales; Education Data Surveys: Oxford, UK, 2008.

106. Edge, K.; Armstrong, P.; Descours, K.; Dapper, E.; Batlle, N. Global City Leaders Study: Research Strategies; Institute of Education, University of London: London, UK, 2013.

107. Miles, M.; Huberman, A. Qualitative Data Analysis: An Expanded Source Book; Sage Publications: Thousand Oaks, CA, USA, 1994.

(c) 2016 by the authors; licensee MDPI, Basel, Switzerland. This article is an open access article distributed under the terms and conditions of the Creative Commons by Attribution (CC-BY) license (http://creativecommons.org/licenses/by/4.0/). 